\title{
The Effectiveness of Youtube as an Online Learning Media
}

\author{
Rahmatika \\ Universitas Sebelas Maret, Indonesia \\ e-mail:Rahmatika.tp@gmail.com \\ Munawir Yusuf \\ Universitas Sebelas Maret, Indonesia \\ e-mail: munawir_uns@yahoo.co.id \\ Leo Agung \\ Universitas Sebelas Maret, Indonesia \\ e-mail:leo.agung@yahoo.co.id
}

\author{
A R T I C L E I N F O \\ Article history: \\ 25 December 2020 \\ Received in revised form \\ 01 January 2021 \\ Accepted 25 January 2021 \\ Available online 03 February \\ 2021 \\ Kata Kunci: \\ Media Pembelajaran \\ Youtobe \\ Keywords: \\ Learning Media, Youtobe
}

\begin{abstract}
A B S T R A K
Covid-19 menyebabkan transformasi pada aspek pendidikkan. Guru mengalami kesulitan saat melaksanakan pembelajaran secara daring. Hal ini disebabkan karena kurangnya media pembelajaran yang dapat memfasilitasi siswa dalam belajar. Penelitian ini bertujuan untuk menganalisis keefektifan Youtube sebagai media pembelajaran online. Jenis penelitian ini adalah penelitian kualitatif. Metode yang digunakan pada penelitian ini adalah metode penelitian kualitatif. Subjek penelitian berjumlah tiga orang guru sekolah dasar. Teknik pengumpulan data dalam penelitian ini adalah wawancara, observasi dan dokumentasi. Teknik analisis data dalam penelitian ini adalah teknik analisis sebelum berada di lapangan dan analisis model Miles dan Huberman. Hasil penelitian yaitu youtobe dapat digunakan sebagai media pembelajaran yang membantu siswa dalam belajar secara mandiri. Orang tua merasa terbantu dengan media pembelajaran Youtube. You tube dapat diakses dengan mudah. Selain itu, media pembelajaran you tube dapat diakses kapan saja dan dimana saja sehingga orang tua tetap dapat mendampingi pembelajaran meskipun mereka sedang bekerja. Sehingga dapat disimpulkan bahwa media pembelajaran Youtube efektif dalam proses pembelajaran daring. Implikasi penelitian ini adalah Youtube dapat digunakan oleh guru
\end{abstract} sebagai media pembelajaran yang dapat membantu siswa dalam belajar. Pemilihan video yang disajikan dalam youtobe harus disesuaikan dengan materi, umur, serta perkembangan psikologis siswa sehingga memudahkan siswa dalam memahami materi yang disajikan pada Youtube.

\begin{abstract}
A B S T R A C T
Covid-19 caused a transformation in the educational aspect. Teachers have difficulty implementing online learning. This is due to the lack of learning media that can facilitate students in learning. This study aims to analyze the effectiveness of Youtube as an online learning medium. This type of research is qualitative research. The method used in this research is qualitative research methods. The research subjects were three elementary school teachers. Data collection techniques in this study were interviews, observation, and documentation. The data analysis technique in this research is the analysis technique before being in the field and the analysis of the Miles and Huberman model. The result of this research is that Youtube can be used as a learning medium that helps students learn independently. Parents feel helped by YouTube learning media. Youtube can be accessed easily. In addition, Youtube learning media can be accessed anytime and anywhere so that parents can still accompany learning even though they are working. So it can be concluded that the YouTube learning media is effective in the online learning process. This research implies that Youtube can be used by teachers as a learning medium that can help students in learning. The selection of videos presented on Youtube must be adjusted to the material, age, and psychological development of students so that it makes it easier for students to understand the material presented on Youtube.
\end{abstract}

\section{Introduction}

A new zoonotic coronavirus that can cause acute respiratory disease in humans, known as COVID-19. Covid-19 is a disease caused by infection with the SARS-CoV-2 virus first identified in the city of Wuhan, in China's Hubei province in December 2019 (Handayani, Hadi, Isbaniah, Burhan, \& Agustin, 2020; Permata \& Bhakti, 2020; Zajacova et al., 2020). Covid-19 has spread to various countries in the world, including Indonesia. The entry of Covid-19 in Indonesia has had a major impact on people's lives, starting from health, economic, social, religious, and educational life (Batubara \& Batubara, 2020; Chang et al., 2020). The impact of the corona virus in the world of education can be seen in the policies of the central to regional governments providing 
policies to dismiss all educational institutions from the level of Early Childhood Education (PAUD) to tertiary institutions (Wulandari \& Purwanta, 2021). Formal, informal, and non-formal educational institutions close faceto-face learning and switch to online learning. Online learning is a new way of teaching and learning that utilizes electronic devices, especially the internet, in delivering learning (Anugrahana, 2020; Dewi, 2020; Sadikin \& Hamidah, 2020). Online learning, completely dependent on internet network access. Online learning is a form of conventional learning that is translated into digital format via the internet. Online learning is considered to be the only medium for delivering material between teachers and students during a pandemic emergency (Rigianti, 2020; Wahyono, Husamah, \& Budi, 2020). The transition of learning, from face-to-face to online learning, raises many obstacles for teachers, considering that this happens suddenly without any prior preparation. In the online learning process, learning media is needed to run effectively. or distance learning (Ayuni, Marini, Fauziddin, \& Pahrul, 2021; Dewi, 2020). Various kinds of learning media can support or assist online learning activities such as WhatsApp, google classroom, quizizz, and youtube (Daheri, Juliana, Deriwanto, \& Amda, 2020; Permata \& Bhakti, 2020; Santosa, Negara, \& Samsul Bahri, 2020; Setiyani, Fitriyani, \& Sagita, 2020; Widyantara \& Rasna, 2020).

Learning media is very necessary to help students to facilitate the learning process, especially with a pandemic like today. Learning media can also attract students' attention during the learning process so that it makes learning meaningful (Prayitno \& Mardianto, 2020; Rosmiati \& Lestari, 2021). Students do not get bored quickly and are motivated to learn. Learning media has a positive influence on student learning outcomes (Maqfiroh, Khutobah, \& Budyawati, 2020; Qumillaila, Susanti, \& Zulfiani, 2017; Yusnia, 2019). In addition, learning media can also increase learning activities and student interest in learning. The use of instructional media can make the delivery of material carried out by the teacher easy. Media can make the learning process more interesting and clear (Hanifah \& Budiman, 2019; Putra \& Sujana, 2020; Rosidah, 2016). Learning media is a means that can attract students' attention in learning. One of the online learning media that can be used is Youtube. Youtube is a media website for sharing online videos that are the most popular in the internet world. Youtube is also a video library service that is provided free of charge to teachers and students to form independent and creative learner characters (Latifah \& Prastowo, 2020). Youtube is a popular video-sharing service where users can load, watch and share video clips for free. Youtube is one of the social media that is practical and easy to access. Youtube creates a conducive learning situation and grows students' interest in learning as learning takes place. Youtube is suitable to be a learning medium that is applied during online learning because it is following the characteristics of elementary school children who are still happy to play, see everything that is visualization like to move, and still like to imitate (Latifah \& Prastowo, 2020; Widyantara \& Rasna, 2020).

Youtube learning media can be accessed anytime and anywhere so that parents can still accompany learning even though they are working. The use of YouTube for online learning at yu tube elementary schools is one of the most popular entertainments on the internet today. Besides being easy to use, Youtube can be accessed anytime and by anyone. Youtube's media excellence is used by educators at the elementary school level. Teachers can create their channels according to the study plan prepared. MI Takmirul Islam uses Youtube as a learning medium. The use of Youtube as a learning medium aims to create interesting, fun, and interactive learning conditions and atmosphere. Youtube is presented with a video that can improve students' understanding of learning. Audiovisual media or instructional videos are media that display audio and visual elements or moving images so that students can see and hear them (Krishna, Sudhita, \& Mahadewi, 2015; Naharir, Dantes, \& Kusmariyatni, 2019; Yuliani, Antara, \& Magta, 2017). The video media that is developed must pay attention to the age and psychological development of students. Media in the form of images, animation, or sound, and videos can be used by teachers as teaching media. Good video media that have been presented in Youtube can be downloaded and then can be used by the teacher to help the learning process. This video media will stimulate students' feelings, thoughts, and willingness to learn through audio-visual presentation of ideas and information (Muskania, Badariah, \& Mansur, 2019; Novita, Sukmanasa, \& Pratama, 2019; Yuniarni, Sari, \& Atiq, 2020). The use of instructional videos can stimulate cognitive development in students so that it can improve student learning outcomes (Febriani, 2017; Purwanti, 2015; Sudiarta \& Sandra, 2016).

Several previous studies have shown that there are several learning media used in the online learning process. Research findings regarding YouTube learning media can improve students' language skills (Widyantara \& Rasna, 2020). Then the research findings regarding the youtube media make it easier for teachers to develop Islamic Islamic education lessons to be more interesting (Latifah \& Prastowo, 2020). Other research was also conducted regarding the WhatsApp media, it was found that online learning via WhatsApp in elementary schools tended to be ineffective (Daheri et al., 2020). There has been no in-depth study of the effectiveness of Youtube as an online learning medium in elementary schools. The purpose of this study was to analyze the effectiveness of learning using youtube media. 


\section{Method}

Research is applied to online learning due to the Covid-19 pandemic situation. This study used qualitative research methods (Sugiyono, 2016). This type of educational research is categorized into four dimensions, namely time, usefulness, objectives, and data collection techniques (Mochtar, 2016). There are three subjects of this research. They are teachers of MI Takmirul Islam Surakarta, students of MI Takmirul Surakarta, and guardians of students of MI Takmirul Surakarta. Data collection techniques in this study were interviews, observation, and documentation. Researchers interviewed teachers and parents. Observations were made when making videos and while studying. Documentation is created while making videos and during lessons. Researchers conducted interviews with teachers, students, and student's parents. The data analysis technique in this study is the analysis technique before being in the field and the analysis of the Miles and Huberman model (Aggelakos, 2007). The analysis technique before going to the field is researcher analyzing preliminary and secondary research. on the preliminary study documents and secondary data

\section{Result and Discussion}

In practice, teachers and schools encounter many obstacles related to online learning (Handarini, Oktafia \& Wulandari, 2020; Sadikin \& Hamidah, 2020; Sobri, Nursaptini, \& Novitasari, 2020). Many teachers do not master the technology so learning at the start of the pandemic is hard and many parents complain about it. Schools also encountered obstacles. Schools are less able to support facilities and infrastructure for the smooth running of online learning. The impact of barriers found by teachers and schools has an impact on the smooth running of online learning. Many parents find it difficult to learn online. They feel that online learning is not effective and efficient in achieving educational goals. In addition, they feel burdened by online learning which leads to increased costs such as buying mobile phones that support online learning and buying internet quota packages. The online learning process requires a learning medium to streamline learning. Learning media are various components in the student environment that can stimulate the learning process, especially during a pandemic. Various kinds of learning media can support or assist online learning activities such as WhatsApp, google classroom, quizizz, and youtube (Daheri et al., 2020; Permata \& Bhakti, 2020; Santosa et al., 2020; Setiyani et al., 2020; Widyantara \& Rasna, 2020). Learning media can also attract students' attention during the learning process so that it makes learning meaningful (Prayitno \& Mardianto, 2020; Rosmiati \& Lestari, 2021). Students do not get bored quickly and are motivated to learn. One of the online learning media that can be used is Youtube.

YouTube is a media website for sharing online videos that are the most popular in the internet world. Youtube is also a video library service that is provided free of charge to teachers and students to form independent and creative learner characters (Latifah \& Prastowo, 2020). The learning videos provided on Youtube can increase students' enthusiasm for learning (Halim, 2017; Pramana, Tegeh, \& Agung, 2016; Utari, 2016). The video in Youtube presents two elements, namely audio and visual, making it easier for students to understand the subject matter. Students who have an audio or visual learning style will find it easier to learn if they use this learning media (Aditya, 2017; Arimbawa, Wiyasa, \& Manuaba, 2017; Puspitasari \& Murda, 2018). Video also has a function, namely overcoming the limitations of space and time, learning becomes more interactive, efficient time and energy, and can be accessed anywhere so that students are easier to learn (Darihastining, Aini, Maisaroh, \& Mayasari, 2020; Desimyari, Putra, \& Manuaba, 2018; Putri, Kusmariyatni, \& Murda, 2018). Learning combined with video media will foster a positive attitude towards the learning process and material in students. In addition, learning videos can also stimulate the knowledge of all students. Videos can train students to think logically, analytically, creatively. Videos can also sharpen students' imaginations so that students can more easily understand the subject matter (Andriyani \& Suniasih, 2021; Wisada, Sudarma, \& Yuda S, 2019). So that through video media, the learning process will be interesting and fun when compared to the information conveyed by the teacher orally in the classroom (Irwandi, 2020; Pratama, Renda, \& Pudjawan, 2018; Widiatmika, Sujana, \& Ganing, 2017). Sometimes some teachers are not proficient in delivering and clarifying subject matter so that students have difficulty understanding the material. So that this video media acts as a tool or facilitates students to clarify the information conveyed by the teacher in class. Many instructional video media are presented on YouTube.

Youtube is suitable to be a learning medium that is applied during online learning because it is following the characteristics of elementary school children who are still happy to play, see everything that is visualization, like to move, and still like to imitate (Latifah \& Prastowo, 2020; Widyantara \& Rasna, 2020). There are many benefits of using Youtube. Youtube can be accessed easily. In addition, Youtube learning media can be accessed anytime and anywhere so that parents can still accompany learning even though they are working. The use of YouTube for online learning at yu tube elementary schools is one of the most popular entertainments on the internet today. Besides being easy to use, Youtube can be accessed anytime and by anyone. Youtube's media excellence is used by educators at the elementary school level. Teachers can create 
their channels according to the study plan prepared. MI Takmirul Islam uses Youtube as a learning medium. Based on the results of the interview, the steps for preparing Youtube as a learning medium include: First, before the learning process begins, the teacher makes a learning video and then uploads it to YouTube. The school must prepare the equipment. Equipment for making instructional videos such as cameras, lights, screens, learning supplies, and school supplies. Teachers are also required to be creative and innovative in making instructional videos. The second step is for the teacher to share a YouTube link according to a predetermined schedule. Learning links are distributed during learning hours. Parents then help students to open and understand learning on Youtube. When students are confused, parents are required to explain the learning again.

The advantage of using YouTube, parents can stop videos when children have difficulty understanding learning. then peers or parents explain slowly until students understand the learning. Another advantage of YouTube is that parents can repeat the video when they have difficulty understanding learning. Third, students and parents see the learning process on YouTube then do the assignments according to the teacher's orders. to find out whether students understand or not learning, the teacher asks questions. practice questions are distributed at the end of the video. The student must take a photo of the answer and then send the photo via WhatsApp. Every Monday the parents collect the tasks that have been done for one week. Not all parents can accompany students to study during the day. When parents work in the morning, they cannot guide students to study. So that parents can guide them at night after work. Through the You Tube learning media, parents can access learning videos that have been shared by the teacher. Parents find it very effective and efficient when they have limited time to guide learning. In addition, you tube learning media can be repeated according to the user's wishes. This can help students who are experiencing learning disabilities and need repetitive learning. The advantages of You Tube are that you can view and upload the videos we like, as a self-promotion event, you can download any video, you can learn to stream, lots of useful videos, there are HD sizes, you can download lots of videos. The results of this study support all research on the use of Youtube as a learning medium. Youtube can improve the language skills of students (Widyantara \& Rasna, 2020). Then the research findings regarding the youtube media make it easier for teachers to develop Islamic Islamic Studies learning to be more interesting (Latifah \& Prastowo, 2020).

\section{Conclusion}

One of the media that can be used in the online learning process is you tube. Parents feel helped by YouTube learning media. Youtube can be accessed easily. In addition, Youtube learning media can be accessed anytime and anywhere so that parents can still accompany learning even though they are working. So it can be concluded that the Youtube learning media is effective in the online learning process.

\section{References}

Aditya, A. (2017). Penggunaan Media Pembelajaran Audio Visual Untuk Meningkatkan Hasil Belajar IPS Pada Siswa Kelas IV SD. Mimbar Sekolah Dasar, 4(1). https://doi.org/https://doi.org/10.23819/mimbarsd.v4i1.5227.

Andriyani, N. L., \& Suniasih, N. W. (2021). Development Of Learning Videos Based On Problem-Solving Characteristics Of Animals And Their Habitats Contain in Science Subjects On 6th-Grade. Journal of Education ..., 5(1), 37-47.

Anugrahana, A. (2020). Hambatan, Solusi dan Harapan : Pembelajaran Daring Selama Masa Pandemi Covid-19 Oleh Guru Sekolah Dasar. Scholaria: Jurnal Pendidikan Dan Kebudayaan, 10(3), 282-289.

Arimbawa, Wiyasa, \& Manuaba. (2017). Pengaruh Model Problem Based Learning Berbantuan Media Audio Visual Terhadap Penguasaan Kompetensi Ips. MIMBAR PGSD Undiksha, 5(2), 1-8. https://doi.org/10.23887/jjpgsd.v5i2.11000.

Ayuni, D., Marini, T., Fauziddin, M., \& Pahrul, Y. (2021). Kesiapan Guru TK Menghadapi Pembelajaran Daring Masa Pandemi Covid-19. Jurnal Obsesi: Jurnal Pendidikan Anak Usia Dini, 5(1). https://doi.org/https://doi.org/10.31004/obsesi.v5i1.579.

Batubara, H. H., \& Batubara, D. S. (2020). Penggunaan Video Tutorial Untuk Mendukung Pembelajaran Daring Di Masa Pandemi Virus Corona. Muallimuna: Jurnal Madrasah Ibtidaiyah, 5(2), 21. https://doi.org/10.31602/muallimuna.v5i2.2950.

Chang, T. Y., Hong, G., Paganelli, C., Phantumvanit, P., Chang, W. J., Shieh, Y. S., \& Hsu, M. L. (2020). Innovation of dental education during COVID-19 pandemic. Journal of Dental Sciences, 1(155). https://doi.org/10.1016/j.jds.2020.07.011.

Daheri, M., Juliana, J., Deriwanto, D., \& Amda, A. D. (2020). Efektifitas WhatsApp sebagai Media Belajar Daring. Jurnal Basicedu, 4(4), 775-783. https://doi.org/10.31004/basicedu.v4i4.445.

Darihastining, S., Aini, S. N., Maisaroh, S., \& Mayasari, D. (2020). Penggunaan Media Audio Visual Berbasis 
Kearifan Budaya Lokal pada Anak Usia Dini. Jurnal Obsesi : Jurnal Pendidikan Anak Usia Dini, 5(2), 1594-1602. https://doi.org/10.31004/obsesi.v5i2.923.

Desimyari, Putra, \& Manuaba. (2018). Pengaruh Model Think Talk Write Berbantuan Media Audio Visual Terhadap Keterampilan Menulis Siswa. International Journal of Elementy Education, 2(3), 28-289. https://doi.org/http://dx.doi.org/10.23887/ijee.v2i3.15969.

Dewi, W. A. F. (2020). Dampak COVID-19 terhadap Implementasi Pembelajaran Daring di Sekolah Dasar. Jurnal Edukatif Ilmu Pendidikan, 2(1). https://doi.org/https://doi.org/10.31004/edukatif.v2i1.89.

Febriani, C. (2017). Pengaruh Media Video terhadap Motivasi Belajar dan Hasil Belajar Kognitif Pembelajaran IPA Kelas V Sekolah Dasar. Jurnal Prima Edukasia, 5(1), 11-21. https://doi.org/https://doi.org/10.21831/jpe.v5i1.8461.

Halim, D. (2017). Pengembangan Video Pembelajaran IPA Pada Materi Pencemaran Dan Kerusakan Lingkungan. Jurnal Pendidikan Sains Indonesia, 5(2), https://doi.org/https://doi.org/10.24815/jpsi.v5i2.9825.

Handarini, Oktafia, I., \& Wulandari, S. S. (2020). Pembelajaran Daring Sebagai Upaya Study From Home (SFH) Selama Pandemi Covid-19. Jurnal Pendidikan Administrasi Perkantoran, 8(3). Retrieved from https://jurnal.unesa.ac.id/index.php/jpap/article/view/8503.

Handayani, Hadi, Isbaniah, Burhan, \& Agustin. (2020). Corona Virus Disease 2019. Jurnal Respirologi Indonesia, 40(2). https://doi.org/https://doi.org/10.36497/jri.v40i2.101.

Hanifah, \& Budiman. (2019). Pengaruh Model Open Ended Problem Berbantu Media Kotak Telur Pelangi ( Kotela ) Terhadap Hasil Belajar. Journal of Education Technology., 3(3), 1-137. https://doi.org/http://dx.doi.org/10.23887/jet.v3i3.21734.

Irwandi. (2020). Penggunaan Media Audio Visual Dalam Peningkatan Hasil Belajar Materi Rukun Iman Pada Siswa Kelas I SD Negeri 49 Kota Banda Aceh. Pionir Jurnal Pendidikan, 9(1), 25-44. https://doi.org/http://dx.doi.org/10.22373/pjp.v7i1.3321.

Krishna, P. D. M., Sudhita, I. W. R., \& Mahadewi, L. P. P. (2015). Pengembangan Media Video Pembelajaran Pada Mata Pelajaran Ipa Siswa Kelas VIII Semester Genap. E-Journal Edutech Universitas Pendidikan Ganesha Jurusan Teknologi Pendidikan, 3(1). https://doi.org/http://dx.doi.org/10.2387/jeu.v3i1.5701.

Latifah, A., \& Prastowo, A. (2020). Analisis Pembelajaran Daring Model Website Dan M-Learning Melalui Youtube Pada Mata Pelajaran Pai Kelas 2 Sd/Mi. Jurnal Limas PGMI, 1(1).

Maqfiroh, Khutobah, \& Budyawati. (2020). Pengembangan Media MOTIF (Monopoli Edukatif) dalam Pembelajaran berbasis Multiple intelligence. Cakrawala Dini: Jurnal Pendidikan Anak Usia Dini, 11(1), 64-74. Retrieved https://ejournal.upi.edu/index.php/cakrawaladini/article/view/24230/12062.

Muskania, R. T., Badariah, S., \& Mansur, M. (2019). Pembelajaran Tematik Menggunakan Media Video Scribe Pada Siswa Kelas IV Sekolah Dasar. Elementary: Islamic Teacher Journal, 7(1). https://doi.org/https://doi.org/10.21043/elementary.v7i1.4927.

Naharir, R. A., Dantes, N., \& Kusmariyatni, N. (2019). Pengaruh Model Pembelajaran Course Review Horay Berbantuan Media Video Pembelajaran Terhadap Hasil Belajar Matematika Siswa Kelas V Semester Ii Sd Gugus Vi Kecamatan Sukasada. MIMBAR PGSD Undiksha, 7(1). https://doi.org/http://dx.doi.org/10.23887/jjpgsd.v7i1.16975.

Novita, L., Sukmanasa, E., \& Pratama, M. Y. (2019). Indonesian Journal of Primary Education Penggunaan Media Pembelajaran Video terhadap Hasil Belajar Siswa SD. 3(2), 64-72.

Permata, A., \& Bhakti, Y. B. (2020). Keefektifan Virtual Class dengan Google Classroom dalam Pembelajaran Fisika Dimasa Pandemi Covid-19. JIPFRI (Jurnal Inovasi Pendidikan Fisika Dan Riset Ilmiah), 4(1), 27-33. https://doi.org/10.30599/jipfri.v4i1.669.

Pramana, Tegeh, \& Agung. (2016). Pengembangan Video Pembelajaran IPA Kelas VI di SD N 2 Banjar Bali Tahun 2015/2016. E-Journal Edutech Universitas Pendidikan Ganesha Jurusan Teknologi Pendidikan, 5(2). https://doi.org/http://dx.doi.org/10.23887/jeu.v4i2.7631.

Pratama, G. H. A., Renda, N. T., \& Pudjawan, K. (2018). Pengaruh Model Pembelajaran Crh Berbantuan Media Audio Visual Terhadap Hasil Belajar Ips. Mimbar Ilmu, 23(1), 128-136. https://doi.org/10.23887/mi.v23i1.16402.

Prayitno, P., \& Mardianto, M. F. F. (2020). Peningkatan Hasil Evaluasi Pembelajaran Daring Saat Pandemi Covid-19 Berdasarkan Media Powerpoint Interaktif. MUST: Journal of Mathematics Education, Science and Technology, 5(2), 171-181. https://doi.org/http://doi.org/10.30651/must.v5i2.6119.

Purwanti, B. (2015). Pengembangan Media Video Pembelajaran Matematika dengan Model Assure. Jurnal Kebijakan Dan Pengembangan Pendidikan, $42-47$. https://doi.org/https://doi.org/10.22219/jkpp.v3i1.2194.

Puspitasari, \& Murda. (2018). Pengaruh Model Pembelajaran IOC Berbantuan Media Audio Visual terhadap Hasil Belajar IPS. Mimbar PGSD Undiksha, 
https://doi.org/http://dx.doi.org/10.23887/jjpgsd.v6i2.19470.

Putra, I. G. D., \& Sujana. (2020). Hasil belajar IPS menggunakan Kolaborasi Model Discovery Learning Berbasis Media Animasi. Journal of Educational Technology, 4, 103-109. https://doi.org/http://dx.doi.org/10.23887/jet.v4i2.25099.

Putri, N. P. L. K., Kusmariyatni, N., \& Murda, I. N. (2018). Pengaruh Model Pembelajaran Inkuiri Terbimbing Berbantuan Media Audio-Visual Terhadap Hasil Belajar IPA. Mimbar PGSD, 6(3), 153-160.

Qumillaila, Susanti, \& Zulfiani. (2017). Pengembangan Augmented Reality Versi Android Sebagai Media Pembelajaran Sistem Ekskresi Manusia. Cakrawala Pendidikan, 34(1), 57-69. Retrieved from https://journal.uny.ac.id/index.php/cp/article/view/9786/pdf. \%0A.

Rigianti, H. A. (2020). Kendala Pembelajaran Daring Guru Sekolah Dasar Di Banjarnegara. Elementary School: Jurnal Pendidikan Dan Kembelajaran Ke-SD-An, https://doi.org/https://doi.org/10.31316/esjurnal.v7i2.768.

Rosidah, A. (2016). Penerapan Media Pembelajaran Visual Untuk Meningkatkan Pemahaman Konsep Siswa Pada Mata Pelajaran IPS. Jurnal Cakrawala Pendas, 2(2). https://doi.org/10.31949/jcp.v2i2.499.

Rosmiati, U., \& Lestari, P. (2021). Inovasi Model Pembelajaran PBI ( Problem Based Instruction ) Berbasis Whatsapp Sebagai Langkah Solutif Pembelajaran di Masa Pandemi Covid-19. JNPM (Jurnal Nasional Pendidikan Matematika), 5(1), 188-197. https://doi.org/http://dx.doi.org/10.33603/jnpm.v5i1.3708 Inovasi.

Sadikin, A., \& Hamidah, A. (2020). Pembelajaran Daring di Tenggah Wabah Covid-19. Jurnal Ilmiah Pendidikan Biologi, 6(2), 214-224. https://doi.org/https://doi.org/10.22437/bio.v6i2.9759.

Santosa, F. H., Negara, H. R. P., \& Samsul Bahri. (2020). Efektivitas Pembelajaran Google Classroom Terhadap Kemampuan Penalaran Matematis Siswa. Jurnal Pemikiran Dan Penelitian Pendidikan Matematika (JP3M), 3(1), 62-70. https://doi.org/10.36765/jp3m.v3i1.254.

Setiyani, S., Fitriyani, N., \& Sagita, L. (2020). Improving student's mathematical problem solving skills through Quizizz. JRAMathEdu (Journal of Research and Advances in Mathematics Education), 5(3), 276-288. https://doi.org/10.23917/jramathedu.v5i3.10696.

Sobri, M., Nursaptini, N., \& Novitasari, S. (2020). Mewujudkan Kemandirian Belajar Melalui Pembelajaran Berbasis Daring Diperguruan Tinggi Pada Era Industri 4.0. Jurnal Pendidikan Glasser, 4(1), 64. https://doi.org/10.32529/glasser.v4i1.373.

Sudiarta, I. G. P., \& Sandra, I. (2016). Pengaruh Model Blended Learning berbantuan Video Animasi Terhadap Kemampuan Pemecahan Masalah dan Pemahaman Konsep Siswa. Jurnal Pendidikan Dan Pengajaran, 49(2). https://doi.org/http://dx.doi.org/10.23887/jppundiksha.v49i2.9009.

Sugiyono. (2016). Metode Penelitian Kualitatif, Kuantitatif, dan R\&D. Bandung: Alfabeta.

Utari, R. (2016). Kontribusi Motivasi Belajar Dan Kebiasaan Belajar Siswa Kelas 1 Teknik Audio Video Terhadap Hasil Belajar Pada Mata Diklat Pkdle Di Smk N 1 Padang. Jurnal Ilmiah Pendidikan Teknik Elektro, 1(oktober 2016), 108-114. https://doi.org/http://dx.doi.org/10.30870/volt.v1i2.2877.

Wahyono, P., Husamah, H., \& Budi, A. S. (2020). Guru profesional di masa pandemi COVID-19: Review implementasi, tantangan, dan solusi pembelajaran daring. Jurnal Pendidikan Profesi Guru, 1(1), 51-65. https://doi.org/https://doi.org/10.22219/jppg.v1i1.12462.

Widiatmika, D. G., Sujana, I. W., \& Ganing, N. N. (2017). Pengaruh Model Discovery Learning Berbantuan Media Audio Visual Terhadap Kompetensi. MIMBAR PGSD Undiksha, 5(2), 1-8. https://doi.org/http://dx.doi.org/10.23887/jjpgsd.v5i2.11786.

Widyantara, I., \& Rasna, I. (2020). Penggunaan Media Youtube Sebelum Dan Saat Pandemi Covid-19 Dalam Pembelajaran Keterampilan Berbahasa Peserta Didik. Jurnal Pendidikan Dan Pembelajarna Bahasa Indonesia, 9(2).

Wisada, P. D., Sudarma, I. K., \& Yuda S, A. I. W. I. (2019). Pengembangan Media Video Pembelajaran Berorientasi Pendidikan Karakter. Journal of Education Technology, 3(3), 140. https://doi.org/10.23887/jet.v3i3.21735.

Wulandari, H., \& Purwanta, E. (2021). Pencapaian Perkembangan Anak Usia Dini di Taman Kanak-kanak selama Pembelajaran Daring di Masa Pandemi Covid-19. Jurnal Obsesi : Jurnal Pendidikan Anak Usia Dini, 5(1). https://doi.org/https://doi.org/10.31004/obsesi.v5i1.626.

Yuliani, Antara, \& Magta. (2017). Pengaruh Video Pembelajaran Terhadap Kemampuan Berhitung Permulaan Anak Kelompok B Di Taman Kanak-Kanak. Jurnal Pendidikan Anak Usia Undiksha, 5(1), 96-106. https://doi.org/http://dx.doi.org/10.23887/paud.v5i1.11309.

Yuniarni, Sari, \& Atiq. (2020). Pengembangan Multimedia Interaktif Video Senam Animasi Berbasis Budaya Khas Kalimantan Barat. Jurnal Obsesi: Jurnal Pendidikan Anak Usia Dini, 4(1). https://doi.org/https://doi.org/10.31004/obsesi.v4i1.331.

Yusnia, Y. (2019). Penggunaan Media Video Scribe Dalam Pembelajaran Literasi Sains Untuk Mahasiswa PGPAUD. Cakrawala Dini: Jurnal Pendidikan Anak Usia Dini, 10(1), 71-75. 
https://doi.org/https://doi.org/10.17509/cd.v10i1.17436.

Zajacova, A., Jehn, A., Stackhouse, M., Choi, K. H., Denice, P., Haan, M., \& Ramos, H. (2020). Mental health and economic concerns from March to May during the COVID-19 pandemic in Canada: Insights from an analysis of repeated cross-sectional surveys. SSM - Population Health, 12, 100704. https://doi.org/10.1016/j.ssmph.2020.100704. 